\title{
СОЦИЈАЛНИ АСПЕКТИ СЛИКЕ СВЕТА У НАПУЉСКОЈ ТЕТРАЛОГИЈИ ЕЛЕНЕ ФЕРАНТЕ
}

\begin{abstract}
Овај рад се бави Напуљском тетралогијом Елене Феранте тумачењем социјалних проблема напуљског друштва представљених у роману, смештајући их у одговарајући друштвени, историјски и културни контекст. Анализом социјалних аспеката, којима ауторка дочарава хронотоп,у раду се осветљава слика послератне Италије приказом Напуља и његових предграђа. Испитује се став Елене Феранте према насиљу као виду комуникације у окрутној атмосфери предграђа, а посебно према насиљу над женама као парадигми односа моћи и виду ограничавања жена. Приказом конфронтиране употребе дијалекта и стандардног језика Феранте ствара метафору за низ других бинарних карактеристика послератне тоталитарне Италије у фази модернизације, попут поделе на Север и Југ, на образоване и необразоване, богате и сиромашне. Анализом културолошких, политичких, социјалних и лингвистичких апстрактних елемената даје се преглед специфичности и дубине наративних нивоа ове саге.
\end{abstract}

Кључне речи: социјални аспект, Елена Феранте, предграђе, Напуљ, дијалект, насиље.

1. Увод. У литерарном стваралаштву понављање доминантних елемената више је правило него изузетак. Сарамаго изнова пише своје визије и интерпретације дистопије; Пиранделов протагониста је готово увек мушкарац који је на ивици лудила јер не може да разлучи шта је истина, а шта фикција; код Кафке очекујемо осећај безнадежности и метафизичког очаја итд. Ако узмемо у обзир мисао да писац увек пише једну књигу изнова и изнова на примеру опуса Елене Феранте могли бисмо да докажемо веродостојност ове хипотезе. Протагониста њених романа је увек образована жена са југа Италије, обично из Напуља, која живи на северу земље, бави се писањем или професуром. Ликови које срећемо у њеним романима су млада мајка растрзана између амбиција и родитељства, мен-

\footnotetext{
${ }^{1}$ aleksandra.djordjevic@fsu.edu.rs
} 
торка - узор, жена коју напушта муж или љубавник. Елементе који се понављају, а који су есенцијални са психолошког аспекта фабуле, налазимо у жељи јунакиње за отклоном од јужњачког дијалекта, затим у осећају одбојности према телу своје мајке из страха да ће се претворити у њу, у опису Напуља или предграђа, те у мотиву лутке који се појављује, како у делу $L a$ figlia oscura (2006), тако и у Напуљском циклусу, као доминантна парадигма односа према мајчинству. Препознатљиве елементе стваралаштва Елене Феранте можемо анализирати и кроз њен специфичан приповедни стил, који подразумева стратегију удвојене нарације и опсежан приказ социјалних аспеката италијанског послератног друштва. Овај рад посвећен је анализи социјалних аспеката слике света у Напуљској тетралогији.

2. АНАЛИЗА СОЦИЈАЛНИХ АСПЕКАТА. Наративни оквир који отвара $H a$ nуљску тетралогију подсећа на увод у Бокачов Декамерон, где наративни оквир има алегорично-реторичку функцију раздвајајући историјске околности и приповедање, са разликом у томе што наративни оквир који формира Феранте јединственом поетиком прави позорницу за причу о генијалној пријатељици, а заправо о односу двеју пријатељица у њиховом детињству, одрастању и зрелом добу. Описујући сазревање протагонисткиња, Феранте нас води кроз духовни и физички развој од детињства до зрелог доба кроз традиционалну когнитивну логику која дефинише протагонисткиње -Елену и Лилу у различитим улогама које су им додељене: у улози кћерке, мајке, супруге, љубавнице и, наравно, пријатељице. Читалац је ,заведен” сугестивним гласом нараторке Елене, која га саучеснички води кроз животе свих ликова. На овај начин нараторка нас смишљено наводи на своју страну приче, док истовремено њено одсуство баријера при описивању, чак и најсрамнијих и најмрачнијих осећања са којима се сусреће, успоставља поверење и интимност остварујући блискост са читаоцем.

Ауторка нас упознаје са ликовима прологом који представља наративни оквир - Елена добија позив од Лилиног сина који јој саопштава да је Лила нестала, избрисавши, како је увек и претила, сваки траг о себи - нестали су одећа, књиге, компјутер, чак и њен лик са свих фотографија. Након што увидимо да се ради о мистериозној жени, пратимо на који начин реагује нараторка, којој је нестанак пријатељице повод за приповедање о овом необичном пријатељству:

Као и обично Лила претерује, помислила сам. Желела је не само да она сама нестане, сада у шездесет шестој години, већ и да прецрта читав живот који јој је стајао иза леђа.Осетила сам велику ьутюу. Видећемо ко ће успети овога пута, рекла сам сама себи. Укључила сам компјутер и почела да пишем сваку појединост из наше прошлости, све оно што ми је остало у глави (FERRANTE 2016a: 19). 
Феранте причу о пријатељству, за које већ из увода сазнајемо да је комплексно и у есенцији компетитивног карактера, смешта у Напуљ и његова предграђа педесетих година двадесетог века. Поред историје пријатељства дугог шест деценија, приповедни стил ауторке формира чврсте оквире нарације постепено упознајући читаоце са променама, препрекама и контрадикцијама које карактеришу Италију после Другог светског рата. Остављајући за собом политику фашизма, Италија је „пригрлила" капиталистички конзумеризам и модерне вредности, па у опису амбијента имамо не само хронику ере промена у италијанској историји већ и приказ конзервативне поделе родних улога. Економски развој познат као „економско чудо” трансформисао је италијанско друштво извлачећи многе Италијане из сиромаштва, нудећи нове могућности у образовању, које омогућава померање на социјалној лествици, што претходним генерацијама није било доступно (BULLARO 2016: 15-45). Међутим, нису све промене које је послератни „економски бум” донео биле позитивне. Поред економског оснаживања људи и демографских промена, јавило се плодно тло за појаву криминала. Већ сам наслов трећег тома - Прича о онима који одлазе и онима који остају указује на то да су неки ликови постали успешни и напредовали и на економској и на друштвеној лествици, а да су други остали у запећку свог предграђа. У позадини приче о пријатељству читалац добија приказ сиромаштва и, са једне стране, сна о успеху средње класе, а са друге, остварењу кошмара кроз политичко насиље. Немири који тресу земљу шездесетих и седамдесетих година постављају контекст сеизмичких промена - протести 1968. године, затим појава Црвених бригада, сукоб комуниста и фашиста, тероризам, виђен и са левичарског и са десничарског становишта. Ове промене Пјер Паоло Пазолини, један од највећих интелектуалаца Италије двадесетог века, назвао је „,антрополошком мутацијом”, посматрајући их кроз призму преласка са традиционалних на модерне вредности. За Пазолинија је ова промена била изразито негативна, јер је водила ка хомогенизацији идеја, укуса, жеља и тежњи ка лажној представи себе коју доноси масовна потрошња (FARRIS 2017: 4).

Ако претпоставимо да је Напуљ родни град Елене Феранте, ${ }^{2}$ онда га можемо посматрати као литерарни катализатор ауторског опуса. Креирајући слику Напуља, који протагонисткиње романа, чини се, доживљавају као град без љубави (FERRANTE 2016а: 185), Феранте граду додаје психолошки контекст кроз сећања, страхове, маштања, али и сензуални контекст, описима мириса, укуса, звукова. Утисак о атмосфери напуљског

\footnotetext{
${ }^{2}$ Елена Феранте је псеудоним који ауторка користи не желећи да открије свој идентитет већ дуги низ година. У више наврата је, међутим, за себе рекла да је из Напуља, али пошто је њен идентитет и даље предмет великих нагађања, не може се са сигурношћу тврдити да је тај податак тачан (ГАМБАРО 2014: 169; ТОРТОРИЧИ 2015: 12).
} 
предграђа - рејона $^{3}$ у коме се одвија радња прве књиге - добијамо постепеним откривањем правила која владају у том свету. Рејон је за Елену и Лилу једини свет за који знају и његове границе чине им се непремостивим, али се оне заправо мењају или бледе сазревањем главних јунакиња. То је место где људи не мењају ставове, судбине се понављају циклично из генерације у генерацију, а деца постају слика и прилика својих родитеља. Описом предграђа Феранте проширује унутрашњи свет романа стављајући у опозицију поимање предграђа из Еленине перспективе са радозналошћу шта се иза граница рејона крије. Напуљска предграђа су парадигма генерација људи који никада нису успели да се еманципују. Феранте дочарава атмосферу описујући жене стиснутих усана и погнутих рамена (FERRANTE 2017a: 102) које су „самлели” мушкарци, трудноће, деца, сиромаштво, насиље и туга, и мушкарце уништене насиљем и корупцијом локалних криминалаца, монархофашиста повезаних са Камором, који су исисали живот из града.

Предграђе Напуља у тетралогији фигурира као својеврстан микрокосмос италијанског друштва. Ликови које упознајемо у првом роману представљају све аспекте друштвеног миљеа послератне Италије и, премда сви потичу са истог социјалног дна, њихов развојни пут је умногоме различит. Ђино постаје фашиста, Пасквале комуниста, браћа Солара постају чланови мафије - камористи, затим имамо приказ радничке класе, миграната попут Антонија, и, наравно, у фокусу наше пажње су Елена и Нино, који постају интелектуалци (SEGNINI 2017: 102). Развојни пут неких ликова је предвидив, док као контраст томе видимо како је Лилин просперитет онемогућен недостатком образовања и омеђен конзервативним очекивањима миљеа у којем она живи.

Када Елена полази у средњу школу, отац је води у центар Напуља по први пут и тај преломни моменат представља рушење баријера, како формативне опресије, тако и физичке.

Границе рејона тог лета су избледеле [...] Да ли је могућно да је само наш рејон био тако пун напетости, док је остатак града зрачио и био благонаклон? [...] У том тако страховитом тренутку, пуном светлости и продорног звука, замислих да сам сама у свему томе новом што представља град, нова ја, са читавим животом испред себе изложена бесовима у покрету, бесовима ствари - али извесно, победница: ја [...] (FERRANTE 2016a: 133-135)

Описом преласка из старог, до тада јединог доступног, света у нови и неистражени, Феранте уједно ствара и метафору рушења баријера у спознаји света кроз ширење видика образовањем.

Социјални аспекти који прожимају и повезују целокупну сагу тичу се елемената свеприсутног насиља, комплексног односа јунакиње према мајци, али и према мајчинству уопште, као и специфичне употребе дијалекта. Ова особена слојевитост даје дубину наративном тону у целој тетралогији.

\footnotetext{
${ }^{3}$ У српском преводу Мирјане Огњановић, италијанска реч rione преведена је речју рејон. У енглеском језику rione је преведен речју neighbourhood.
} 
3. НАСИЉЕ КАО НАЧИН ЖИВОТА. Креирајући ЛиЛИН развојни Пут и оПисујући њене животне крахове, Феранте приказује Напуљ као место где су жене инфериорне, малтретиране и тлачене од тренутка рођења, а судбина им се у значајној мери погоршава удајом. Већ на првим странама саге Феранте описује рејон као место где је насиље не само прихваћено већ и очекивано, чинећи га простором где је народ ускраћен за срећу (ФЕРАНТЕ 2016а: 185). Деца се гађају камењем, очеви туку децу, жене се чупају, гађају посуђем, мужеви туку своје жене, а оне на то узвраћају јединим расположивим средством - увредама. Насиље за припаднике рејона представља општеприхваћени вид комуникације. Однос према насиљу у приповедном тону нараторке је помирљив, чињенични, готово лежеран и служи да дочара амбијент више него да изазове реакцију.

Насиље над женским телом, са друге стране, приказује однос моћи који поставља границе.

Одрасле смо верујући да никакав странац не сме ни да нас такне, али да родитељ, вереник и муж могу да нас шамарају кад им се прохте, из љубави, како би нас васпитали или преваспитали (ФЕРАНТЕ 2017а: 51).

Описујући женске ликове и ситуације у којима оне трпе насиље, запажамо да је физичко насиље само најочигледнија манифестација читавог спектра злостављања, од психолошког преко вербалног до емотивног, и да оно обликује жене рејона од самог детињства. Оне га не само подносе већ га и прихватају као легитиман вид комуникације. Пример за овакав вид опхођења налазимо у Лилиној исповести Елени, када јој, жалећи се на мужа, каже: Не жели виме да имам једну једину мисао која је само моја, и ако открије да сам му прећутала било какву неважну ствар, пребије ме (ФЕPAHTE 2017a: 406).

Иако је Лилин лик приказан као неустрашив, ограничен је њеним телом, чиме јој се одузима моћ побуне. Први пут то видимо када је отац, после њеног предлога да настави школовање, не само претуче већ и избаци кроз прозор као да је ствар (ФЕРАНТЕ 2016а: 79), сломивши јој руку. Затим, њен други велики крах дешава се прве брачне ноћи када схвата да њена побуна и моћ зависе само од физичке снаге мушкарца против којег се бори. Ошамари је два пута прво дланом, а затим надланицом, толико снажно да јој постаде јасно да ће је, уколико настави да му се опире, засигурно убити (ФЕРАНТЕ 2017: 40). Осујећење њене побуне корак је даље од еманципације ка којој обе протагонисткиње стреме, а Лилино тело пуно модрица после прве брачне ноћи симболизује динамику физичке моћи у браку у рудиментарној средини рејона. Њено посустајање није чин предаје, већ последица физичке надмоћи као јединог аргумента којем мушкарци прибегавају у одмеравању снага са женама тог доба.

Читаоцу постаје сасвим јасно да је њена јединствена генијалност и жеља за бегом од опресије довољна да оде из Напуља и скине окове које јој 
jе то маскулино друштво наметнуло, али загонетност њеног лика таква је да никада не добијамо објашњење зашто, упркос свему, она то ипак не чини. Формирајући готово опозитне личности, Феранте имплицитно наглашава дихотомију у креирању наративног идентитета - Лила је тело заробљено у граду без перспективе, а Елена дух који одлази из града да оствари свој потенцијал. Док Лила поништава границе сопственог тела кроз процес који назива smarginatura, ${ }^{4}$ Елена раствара границе родне неједнакости и класног идентитета (ФАРИС 2017: 6). Лилино растварање граница је сирово и опипљиво, она га доживљава кроз своје тело, као мешавину синестезије, губљења осећаја и утапања у свет око себе, док је Еленино рушење баријера фигуративно и метафизичко. Извор динамике односа двеју пријатељица огледа се, сматра Максимович (2016: 207-236), у њиховој континуираној амбивалентној потреби за аутономијом и индивидуалношћу. Елени је ова прилика за самоактуализацију омогућена, како сазнајемо на крају саге, кроз писање билдунгс романа о себи, док је овог пута Лила прешла у сферу ефемерног, неставши на крају романа, бришући своје границе. Smarginatura, иако је њен највећи страх, овим би потезом могао бити финални чин самоостварења.

Однос јунакиња према Напуљу и рејону може се метафорично представити сликом Лилиног светла које је могло да сија само у мраку рејона, док се Еленино распламсавало удаљавањем од њега. Ове чињенице и Елена постаје свесна посматрајући Лилу како се удајом за типичног представника тог света на известан начин заувек везује за рејон. Уједно, постаје јој јасно да је образовање једини начин да се од рудиментарног света рејона удаљи и тако га победи.

Лила је остала ту, ограничена на блистав начин на тај свет, од којег је измислила да је извукла најбоље. Ништа што би имало везе са мојим путем учене девојке (ФЕРАНТЕ 2016а: 321).

Као антитезу томе, у трећој књизи - Причи о онима који одлазе и онима који остају, Феранте, измештајући је из Напуља, Елену описује као жену која је прерасла границе родног града, али истовремено остала заробљена у његовим културолошким и моралним оквирима. Идеја од које Елена највише страхује огледа се у бојазни да је њена судбина предодређена колективним усудом рејона. И заиста, на крају трећег тома, Напуљ је тај који је „надмудри” и однесе победу, јер, упркос дугогодишњем презиру и жељи да се дистанцира од Напуља, Елена оставља свог супруга који потиче из аристократске породице о каквој је одувек маштала и, мимо сваке логике, вођена страшћу, бира Нина, враћајући се својим коренима у Напуљ. Елена се враћа у свој рејон и увиђа да је исти као и када га је напустила: насиље, неписменост, дезорганизованост и главну реч и даље воде мушкарци и мафија.

4 У поетици Елене Феранте појам smarginatura представља растварање, урушавање граница, али и њихово међусобно преплитање, што доводи до стања нејасности и несигурности (БУЛАРО, ЛОВ 2016: 5). 
4. ЈЕЗИК КАО ПАРАДИГМА ГРАНИЦА. ВремеНско-ПросторНа Повезаност у оквиру наративног тона и садржаја остварена је одабиром језика којим ликови говоре. Феранте имплицитно описује вековну проблематику „questione della lingua" конфронтирајући употребу стандардног италијанског језика и дијалекатског говора. „Лингвистичке и металингвистичке стратегије воде читаоца на улице Напуља где звуци напуљског дијалекта боје свакодневни живот" (КАВАНО 2016: 46). Језик и образовање у двадесетом веку чине кључну социоекономску промену. Промена доминације стандардног језика над дијалектом у основи је интерперсоналних релација радничке класе ликова у Напуљској тетралогији. Образовање као кључни елемент у прва два тома функционише као модернистички хронотоп у приповедном тону Феранте. Опозиција између школе и рејона служи као примарни метоним и метафора за низ других бинарних карактеристика послератне тоталитарне Италије у фази модернизације, попут дихотомије Север - Југ, стандардни језик - дијалект и опозиција у животу Елене кроз однос менторка-мајка, Лила-Елена (ЛОВ 2016: 71-99). Дијалект стога служи и као стилско средство описа социјалне припадности. Маргинални ликови попут Лилиних родитеља или мужа изражавају се искључиво користећи дијалект, што их смешта и фигуративно и просторно у границе рејона. За разлику од њих, постоје ликови који се никада не изражавају дијалектом, користећи искључиво софистицирани стандардни италијански језик, попут породице Елениног мужа (СЕЊИНИ 2017: 113).

Пратећи избор протагонисткиња да употребе дијалект или италијански језик можемо посматрати и њихове развојне карактеристике. На почеку приче, када се упознају, Елена описује Лилу као дивљу девојчицу која се изражава агресивним дијалектом, међутим како почиње њено образовање и сазревање, она постаје веома вешта у употреби префињеног језика. Ипак, она не запоставља дијалект, већ га користи као оружје када јој је потребан другачији приступ у зависности од саговорника или ситуације:

[...] стално је говорила на дијалекту попут свих нас, али по потреби, сипала је из рукава италијански као из књиге, користећи и речи као што су прикладно, раскошно, драговољно.

[...] зато што је имала поган језик, измишљала је понижавајуће надимке, па иако је са учитељицом низала речи италијанског језика које нико познавао није, с нама је причала искључиво на љутом дијалекту, препуном ружних речи [...] (FERRANTE 2016a: 44, 58).

Елена, међутим, превазилази границе које поставља дијалекат. Временом осећа све већу дистанцу према језику свог детињства и дијалект као баријера на путу еманципације временом избледи. Када је реч о употреби дијалекта у циљу дочаравања атмосфере предграђа и класне огољености, необично је важно истаћи да Феранте у читавој тетралогији уопште не пише дијалектом. Ефекат дочаравања разлике између дијалекта и књижевног језика постиже веома једноставном техником: 
Лутака није било, Лила је понављала на дијалекту: нема их, нема их [...]

Рече мирно на дијалекту: Још једном је пипни, има да ти покажем шта ће да ти се деси (FERRANTE 2016а: 52, 132).

Пинуча се злобно осмехну и рече на дијалекту: полако учи.

Разговор који је уследио био је читав на дијалекту, као да напетост спречава напорно пречишћавање изговора, лексике, италијанске синтаксе (FERRANTE 2017a: 29, 73).

Упитана зашто се служи таквим приповедним стилом, ауторка одговара објашњењем да ју је дијалект њеног детињства и адолесценције често плашио, па је у својим делима одабрала илузију еха дијалекта, који фигурира попут претње стандардном италијанском језику (FERRANTE 2016б: 220).

5. НАПУљ КРОЗ СИМБоЛ МАЈчИНСтвА. Мајка је фигура од необичног значаја у целом опусу Елене Феранте. Било да однос мајке и кћерке тумаче у кључу психоанализе, феминизма или анализирајући жељу за отклоном од унапред утврђеног модела, овај однос је тема многобројних научних радова који обрађују, како рана дела ове списатељице (в. ALSOP 2014), тако и Напуљьки цүиклус (в. MILKOVA 2013; БОБИЧИЋ 2017), те захтева опсежну анализу. Једна од интерпретација комплексног односа Елене и Лиле заснива се на покушају да се њихов однос чита у психоаналитичком кључу као однос мајке и кћерке (МАКСИМОВИЧ 2016: 207-235). Симболични однос мајке и кћерке представљен је кроз читав спектар осећања: пружа задовољство, мотивише, омогућава напредак, али је истовремено и деструктиван, паразитски и застрашујућ. Попут праве мајке и кћерке, Лила и Елена често имају потребу за дистанцом како би раздвојиле своје идентитете, јер константно надгледају једна другу и осећају се повређено, чак и параноично када једна од њих две изађе из оквира свог утврђеног идентитета. Лила очекује од Елене да живи животом који њој није био омогућен, али када Елена искорачи из оквира који Лила може да појми, Лила јој презриво замера, исто као што то чини и њена мајка. Феранте у целој приповести описује Еленин презир према мајци, наглашава њен амбивалентан однос према мајчинству и проблематизује однос родитељ-дете, као и жељу за отклоном од утврђеног модела. Еленин страх да ће се почети да личи на своју мајку доминантан је аспект њеног приповедног тона у сва четири тома Hanyљcке тетралогије. Ауторка нуди објашњење овог феномена наводећи да се у конзервативном свету рејона жеља да се надмаши родитељ сматрала готово знаком непоштовања, те у једном тренутку и сама нараторка почиње помирљиво да гледа на своје мајчинство тумачећи га природним поретком: постати попут мајки из рејона није више клетва, већ природан ток ствари (ФЕРАНТЕ 2017б: 284). У књизи која обрађује тему мајчинства у италијанској литератури, Лаура Бенедети (2007: 94) наводи да су феминистичке тек- 
стове седамдесетих година двадесетог века писале управо ауторке - кћерке, које су се генерацијски буниле против свега што су њихове мајке представљале. Елена и Лила не желе да живе животом укалупљеним по моделу својих мајки и обе су тога свесне, али оно што не признају јесте да обе желе да моделују себе према идеалу које су приписале једна другој. Нараторка то често илуструје дајући нам увид у своја осећања: Оно што бих могла да постанем ван Лилине сенке није имало никаквог значаја (ФЕРАНТЕ 2017а: 25), али и наводећи Лилине речи: [...] од тебе очекујем све најбоље, знам врло добро да можеш боље од овога, желим да будеш боља, јер шта сам ја ако ти ниси добра? (ФЕРАНТЕ 2017б: 281).

По повратку у Напуљ Елена постаје свесна да је рејон место где су њени пријатељи постали попут својих родитеља. Пасквале, син комунисте који је убио дон Акилеа, и сам постаје комуниста, такорећи идеолошки терориста, члан Црвених бригада, Ђино је фашиста, попут својих родитеља, браћа Солара камористи су као и њихов отац, Стефано, Лилин муж се од дивног осећајног младића преобразио у свог оца, насилног, поквареног неотесаног баука дон Акилеа. Лилу је, као и њену мајку и све жене рејона, „сломио” брак, док је Нино, који се као младић заклео да никада неће бити налик оцу, наизглед диван породични човек, а заправо неверни лицемер, постао управо слика и прилика свог оца - човек који оставља своје љубавнице на ивици разума.

У овом раду поменућемо још један од многих аспеката овог односа - страх од поистовећивања са мајком и жељу за отклоном од ње симболично повезану са напуштањем Напуља. Описујући веома мучан и у основи амбивалентан однос са мајком, нараторка нас у последњем тому води ка катарзичном моменту када мајка умире и када се њеном смрћу симболична пупчана врпца са Напуљем прекине. Као резултат, иако и даље живи у рејону, Елена више не осећа блискост са својим градом. Њена одбојност према рејону је након смрти мајке прешла у помирљиву зрелост, која јој најзад даје могућност да сагледа објективно свој град, без страха, без страсти. Могло би се рећи да Елена на тај начин побеђује своје корене и више не осећа страх према Напуљу. При самом крају четвртог тома насловљеног Прича о изгубљеној девојчици, проматрајући своје кћери, Елена закључује како је важно да се оне нису сусреле са потешкоћама које је она морала да превазиђе: Али ја, ја која нисам имала привилегије, ја сам темељ юихових привилегија (ФЕРАНТЕ 2014: 436). Нараторка најзад осећа сатисфакцију, јер је стицањем аутономије и образовањем успела да направи велики искорак на путу слободе.

Помислила сам на то колико рада стоји иза мене и колико сам тога успела [...] Напустила сам рејон, вратила се, успела опет да одем. Ништа ме није одвукло на дно, ни мене ни моје девојчице. Сигурне смо. Успела сам да их заштитим (ФЕРАНТЕ 2014: 435). 
Међутим, поетички кључ за тумачење моћи коју у наративном стилу Феранте носе корени откривамо на самом крају саге када, стварајући противтежу односа моћи, град другој хероини - Лили задаје финални ударац отевши јој кћерку. Овај трагични обрт поклапа се са исконским страхом нараторке, и метафоричким и реалним, да би предграђе у свој својој суровости могло да прогута њене потомке и не дозволи им да се од њега отргну. Ауторка овим потезом прави позорницу на којој је Напуљ еволуирао у трећег протагонисту епопеје - надмоћног супарника, непредвидивог до самог краја, мрачног зликовца који не може бити поражен, чак ни када има неприкосновеног противника попут Лиле.

6. ЗАКључАк. Премда је Напуљьска тетралогија превасходно прича о мотивишућој али и разорној снази пријатељства, истовремено је и прича о друштвеном стању у послератној Италији. Ауторка успева да наведе апстрактне елементе романа, од психолошких и филозофских до социјалних и лингвистичких, да гравитирају ка хронотопу и кроз њега остваре наративну дубину, а то је један од најважнијих фактора који су учинили да опус Елене Феранте постане значајна ставка италијанске књижевне сцене двадесет првог века.

Обе протагонисткиње Напуљске тетралогије поседују снажан феминистички нагон за отклоном од конзервативног маскулиног друштва у којем живе, па се лепота приказа њихових крајње различитих животних путева очитава управо у истицању специфичних контраста њихових живота у Напуљу или рејону и ван њега. Рељефност Лилиног лика карактеришу екстремне супротности у опису њеног изразито тешког живота у Напуљу који она ипак не пристаје да напусти. Као контраст томе, Феранте нуди Еленину жељу за еманципацијом, образовањем, изборе и животни пут као симбол дистанцирања од колективног усуда који са собом носе корени. Међутим, у константном стремљењу да се удаљи од својих корена, од Напуља као симбола ограничености и конзервативизма, бојазни да се не претвори у своју мајку и непрекидном надметању и поређењу са Лилом стиче се утисак да је протагонисткиња Елена померила фокус са примарне тежње самоостварења - способности да буде срећна.

\section{Цитирана литература}

ALSOP, Elisabeth. „La fascinazione di morte in Elena Ferrante's L'amore molesto and I giorni dell'abbandono". Italica 91(3), American Association of Teachers of Italian, 2014, 466-485.

BENEDETI, Laura. The Tigress in the Snow: Motherhood and Literature in TwentiethCentury Italiy. Toronto: University of Toronto Press, 2007. 
BENEDETI, Laura. „Il linguaggio dell'Amicizia e della città: L'amica geniale di Elena Ferrante tra continuità e cambiamento", Quaderni d'Italianistica 33:2, 2012.

BOBIČIĆ, Nađa. „Naći svoje mesto u lancu ženske istorije: matrilinearnost u opusu Elene Ferante“, Genero 21:1-18, 2018.

BULLARO, Grace Russo, The Era of the "Economic Miracle" and the Force of Context in Ferrante's My Brilliant Friend In The Works of Elena Ferrante. Reconfiguring the Margins, New York: Palgrave McMillan, 2016, 15-45.

BULLARO, Grace Russo, and Love, StephanieV. The Works of Elena Ferrante: Recofiguring the Margins. New York: Palgrave McMillan, 2016.

CAVABAUGH, R. Jullian, „Indexicalities of Language in Ferrante's Neapolitan Novels: Dialect and Italian as Markers of Social Value and Difference“. In The Works of Elena Ferrante. Reconfiguring the Margins, edited by Grace Russo Bullaro and Stephanie V. Love, New York: Palgrave McMillan, 2016, 45-71.

LOVE, Stephanie V. „An Educated Identity”: The School as a Modernist Chronotope in Ferrante's Neapolitan Novels. In The Works of Elena Ferrante. Reconfiguring the Margins, edited by Grace Russo Bullaro and Stephanie V. Love, New York: Palgrave McMillan, 2016, 71-99.

MAKSIMOWICZ, Christine. „Maternal Failure and Its Bequest: Toxic Attachment in the Neapolitan Novels". In The Works of Elena Ferrante. Reconfiguring the Margins, edited by Grace Russo Bullaro and Stephanie V. Love, New York: Palgrave McMillan, 2016, 207-236.

MILKOVA, Stiliana. „Mothers, Daughters, Dolls: On Disgust in Elena Ferrante's La figlia oscura". Italian Culture 31(2) )2013): 91-109.

SEGNINI, Lisa. „Local Flavour vs Global Readerships: The Elena Ferrante Project and Translatability“. The Italianist, vol.37, no.1, University of British Columbia and Simon Fraser University, Canada, 2017, 100-118.

TORTORICI, Dayna, „Those like us: on Elena Ferrante“, N+1, 22 (Spring 2015). $<$ https:// nplusonemag.com/issue-22/reviews/those-like-us/> 16. 7. 2018.

FARRIS, R. Sara. „There is no True Life, If Not in the False One: On Elena Ferrante'sNeapoletan Novels“. February 20. 2012. <http://www. historicalmaterialism.org/book-review/there-no-true-life-if-not-false-one-elenaferrantes-neapolitan-novels> 5. 8. 2018.

ШУЛЕВИЦ 2015: Shulevitz, Judith „The hypnotic Genius of Elena Ferrante“, The Atlantic, October 2015. $<$ https://www.theatlantic.com/magazine/archive/2015/10/ the-hypnotic-genius-of-elena-ferrante/403198/> 17. 7. 2018.

\section{Извори}

FERRANTE, Elena. Storia della bambina perduta. Roma: Edizioni e/o, 2014.

FERRANTE, Ferante, Elena. Moja genijalna prijateljica. Beograd: Booka, 2016 (a).

FERRANTE, Ferrante, Elena. Frantumaglia: Writer's Journey. Melbourne: Text Publishing, 2016 (б). 
FERRANTE, Ferante, Elena. Priča o novom prezimenu. Beograd: Booka, 2017 (a).

FERRANTE, Ferante, Elena. Priča o onima koji odlaze i onima koji ostaju. Beograd: Booka, 2017 (б).

Aleksandra A. Đorđević

\section{SOCIAL ASPECTS OF THE PICTURE OF THE WORLD IN THE NEAPOLITAN TETRALOGY OF ELENA FERRANTE}

This paper analyzes the Neapolitan tetralogy written by Elena Ferrante by interpreting social problems presented in the novels. Examining numerous social, cultural and historical aspects that Ferrante uses in her chronotope narrative, we are given the portrayal of post world war Italy through the description of Naples and its outskirts. The article interprets the violence in the novels as a form of communication in the cruel atmosphere of Naples, and especially the violence as a paradigm of power relation between men and women. Depicting the confronting use of dialect and standardized Italian, Ferrante makes a metonym and a metaphor for the series of other binary characteristics of totalitarian Italy such as the North - South dichotomy, the educated and the uneducated, the rich and the poor. Analyzing the cultural and the linguistic abstract elements in the yearning for the social upward mobility of the protagonists in the Neapolitan tetralogy, the paper offers the insight into the specific uncanny narrative of Elena Ferrante.

Keywords: social spects, Elena Ferrante, Naples, neighbourhood, dialect, violence. 